\title{
Need for coordinated programs to improve global health by optimizing salt and iodine intake
}

\author{
Norm R. C. Campbell, ${ }^{1}$ Omar Dary, ${ }^{2}$ Francesco P. Cappuccio, ${ }^{3}$ \\ Lynnette M. Neufeld, ${ }^{4}$ Kim B. Harding, ${ }^{4}$ and Michael B. Zimmermann ${ }^{5}$
}

Suggested citation Campbell NRC, Dary O, Cappuccio FP, Neufeld LM, Harding KB, Zimmermann MB. Need for coordinated programs to improve global health by optimizing salt and iodine intake. Rev Panam Salud Publica. 2012;32(4):281-6.

\begin{abstract}
High dietary salt is a major cause of increased blood pressure, the leading risk for death worldwide. The World Health Organization (WHO) has recommended that salt intake be less than $5 \mathrm{~g} /$ day, a goal that only a small proportion of people achieve. Iodine deficiency can cause cognitive and motor impairment and, if severe, hypothyroidism with serious mental and growth retardation. More than 2 billion people worldwide are at risk of iodine deficiency. Preventing iodine deficiency by using salt fortified with iodine is a major global public health success. Programs to reduce dietary salt are technically compatible with programs to prevent iodine deficiency through salt fortification. However, for populations to fully benefit from optimum intake of salt and iodine, the programs must be integrated. This review summarizes the scientific basis for salt reduction and iodine fortification programs, the compatibility of the programs, and the steps that need to be taken by the WHO, national governments, and nongovernmental organizations to ensure that populations fully benefit from optimal intake of salt and iodine. Specifically, expert groups must be convened to help countries implement integrated programs and context-specific case studies of successfully integrated programs; lessons learned need to be compiled and disseminated. Integrated surveillance programs will be more efficient and will enhance current efforts to optimize intake of iodine and salt. For populations to fully benefit, governments need to place a high priority on integrating these two important public health programs.
\end{abstract}

Key words Sodium; sodium chloride, dietary; iodine; iodine deficiency; nutrition, public health; hypertension; hypothyroidism; hyperthyroidism.

In 2007, the World Health Organization (WHO) organized an expert con-

1 Libin Cardiovascular Institute of Alberta, University of Calgary, Calgary, Alberta, Canada.

2 Abt Associates, Bethesda, Maryland, United States of America.

3 University of Warwick, World Health Organization Collaborating Centre for Nutrition, Coventry, West Midlands, United Kingdom.

4 Micronutrient Initiative, Ottawa, Ontario, Canada.

5 International Council for the Control of Iodine Deficiency Disorders, Eidgenössische Technische Hochschule, Zürich, Switzerland. Send correspondence to: Michael B. Zimmermann, michael.zimmermann@hest.ethz.ch sultation in Luxembourg to discuss the use of salt as a vehicle for iodine fortification (1) and its compatibility with the recommendations for reducing salt intake that emerged from a WHO expert consultation held in Paris in 2006 (2). The catalysts for the Luxemburg meeting were twofold: the concern that the recommendations for reducing salt intake could jeopardize the progress achieved in preventing iodine deficiency disorders through salt iodization programs and, conversely, the concern that permanent advocacy for salt iodization programs could reduce the impact of policies of salt reduction for preventing cardiovascular disease in the population. At the Luxembourg meeting, the basic compatibility of these two important health policies was recognized. Nineteen recommendations came from this expert consultation, many of which touched on the convergence of these two policies. Unfortunately, there were no major initiatives toward developing a framework that would show how these policies 
could be implemented harmoniously until January 2011 when the Pan American Health Organization (PAHO)-WHO initiated discussions on how to coordinate programs to ensure optimal intake of iodine and salt. The resulting PAHOWHO meetings on harmonization of iodine and salt programs stimulated much discussion. This manuscript, which resulted from those discussions, provides recommendations to $\mathrm{WHO}, \mathrm{WHO}$ regional offices, international public health agencies, national governments, and health care professional and scientific organizations on actions that are likely to improve population health through optimized intake of iodine and salt. The recommendations represent the opinions of the authors but do not reflect the official position of $\mathrm{PAHO}-\mathrm{WHO}$ or other organizations.

\section{SODIUM, SALT, ${ }^{6}$ AND HEALTH}

Humans require sodium, and the natural ingredients-without added salt_-of the usual diet provide adequate amounts. However, dietary habits acquired recently in human evolution provide excessive amounts of salt both through discretionary salt that consumers add to food at the table and when cooking and, more recently, through salt that the food industry adds to products during the manufacturing process (3, 4). High salt intake increases the risk of many health disorders, and a typical modern diet provides a 10-fold excess of salt compared with traditional diets during human evolution (5).

High salt intake is causally linked to increased blood pressure, the leading risk factor for death and the second leading risk factor for disability by causing heart disease, stroke, kidney failure, and other vascular diseases (5). Worldwide, about one in four adults has hypertension; data from the Framingham study estimate that more than $90 \%$ of people living an average lifespan will develop hypertension $(6,7)$. The direct health costs of nonoptimal blood pressure (i.e., systolic pressure greater than

\footnotetext{
In most of the world, the vast majority of dietary sodium intake is sodium chloride, commonly referred to as simply "salt." Decreased dietary sodium (salt) intake implies a reduction of total sodium intake from all dietary sources including, for example, nonchloride salts of sodium such as monosodium glutamate. This manuscript uses the term "salt" when referring to total sodium.
}

$115 \mathrm{mmHg}$ ) are estimated to be about $10 \%$ of overall health care expenditures worldwide (8). High dietary salt is associated with about $30 \%$ of hypertension (9). Although a long-term randomized controlled trial has not been conducted to examine the impact of lowering dietary salt on death and disability, a vast and consistent array of evidence from animal studies; cross-sectional, migration, and cohort studies; observational trials; population interventions; and post hoc analysis of long-term trials strongly indicate that high intake of dietary salt is a major contributor to death and disability due to cardiovascular disease $(5,10-12)$. In the United States of America, high dietary salt is estimated to be the seventh leading risk factor for premature death; in middle-income countries, such as Chile, it is the second leading risk factor for death $(13,14)$. In low-income countries, the burden of illness associated with high salt intake is similarly high (15). Other important causes of death and disability such as gastric cancer, obesity, kidney disease, and osteoporosis have a strong pathophysiological basis for being caused in part by high salt intake (5). Finally, high salt intake in children and adolescents might contribute to high energy intake by increasing thirst and consumption of sugar-containing drinks (5). Although individual variability in the health benefits of reducing dietary salt as a result of both genetic (e.g., genetically controlled sodium transporter function) and environmental (e.g., dietary potassium) variation is expected, reducing intake of dietary salt is indicated to be one of a few "best buys" for improving a population's health (16). WHO has recommended reducing salt intake to less than $5 \mathrm{~g} /$ day [and sodium intake to less than $2 \mathrm{~g} /$ day ( $5 \mathrm{~g}$ of salt is $87 \mathrm{mmol}$ of sodium chloride containing $2 \mathrm{~g}$ of sodium)] in adult populations $(2,17)$.

Programs to reduce dietary salt are estimated to be cost saving in developed countries and are indicated to be one of the most cost-effective interventions to improve health in both developing and developed countries $(11,15,18)$. In lowand middle-income countries, a program to reduce salt intake by $15 \%$ would cost between $\$ 0.04$ and $\$ 0.32$ (U.S. dollars) per person per year, averting more than 8.4 million cardiovascular-related deaths over 10 years (15).

\section{IODINE AND HEALTH}

Iodine is necessary for the production of thyroid hormones, which are essential for, among other things, development of the central nervous system (19). In many areas of the world, including developing and developed countries, the natural diet does not provide adequate iodine (20). It is estimated that approximately two billion people worldwide have inadequate intake of dietary iodine and are at risk of iodine deficiency if iodine is not supplied intentionally (21). Severe iodine deficiency causes hypothyroidism, with mental and growth retardation, and can result in children born with cretinism related to maternal iodine deficiency (19). Mild-to-moderate deficiency can impair cognitive development in infants and children (22). The spectrum of iodine deficiency disorders affects the entire population, but infants and pregnant and lactating women are most vulnerable (23). There are also potential health risks such as thyroid dysfunction that can result from excess iodine, but the health benefits of iodine fortification programs vastly outweigh potential risks.

The current recommendations of WHO-United Nations Children's Fund (UNICEF)-International Council for the Control of Iodine Deficiency Disorders (ICCIDD) for adequate iodine intake are $150 \mu \mathrm{g} /$ day for adults, with the exception of pregnant and lactating women whose recommended intake is $220-290 \mu \mathrm{g} /$ day (24). WHO-UNICEF-ICCIDD (21) established the recommended iodine intake to cover the needs of $97.5 \%$ of pregnant and lactating women at $250 \mu \mathrm{g} /$ day (24). The main strategy recommended by WHO and UNICEF for controlling iodine deficiency disorders is universal salt iodization, which consists of adding iodine (as iodate or iodide) to all salt for human consumption, including salt used in food processing (25). Salt is generally considered the preferred food vehicle for iodine fortification because it is consumed by almost everyone, its production is often limited to a few sites (facilitating quality control), its taste or odor is not changed by the presence of iodine, and it is extremely inexpensive (26). Salt iodization is a highly effective, low-cost intervention (27).

Although salt iodization programs have been successful in many coun- 
tries, there is room for improvement and iodine deficiency continues to be a health problem in both developing and developed countries (28). About 50\% of continental Europe remains mildly iodine deficient (29), and iodine intake in other developed countries-including the United States, the United Kingdom, and Australia-has fallen in recent decades, possibly due to reduced use of iodine-containing disinfectants by the dairy industry and the lack of incorporation of iodine in most commercial processed foods (many countries do not mandate or use iodized salt in processed foods) (30-32). In the United States, although the general population appears to be iodine sufficient, it is uncertain if iodine intake during pregnancy and lactation is adequate (33). Recent unpublished data from Canada also suggest that some young women may have marginal intakes of iodine. These changes emphasize the importance of regular, systematic monitoring of iodine status and iodization programs. In contrast, in most Central and South American countries and in many African and Asian countries, salt iodization has resulted in sustained control of iodine deficiency disorders, although gaps in monitoring exist and up-to-date information is not available in many cases (28). Among the WHO regions, the lowest prevalence of iodine deficiency in school-aged children is found in the Americas (10.6\%), where the proportion of households consuming iodized salt is the highest in the world $(\approx 90 \%)(21,28)$.

\section{DIETARY IODINE, IODINE IN FOOD FORTIFICATION, AND IODIZED SALT}

Most foods are low in iodine in relation to physiological needs (20). Only marine foods and milk products from animals reared with iodine-enriched feeds or pastured on iodine-rich soils contain high amounts of iodine. However, for most countries these foods constitute a minor component of the diet, and therefore dietary iodine intakes are low. Although universal salt iodization programs call for iodizing all salt, including household (cooking and table) and food industry salt, household salt has been the main fortification vehicle to provide iodine. In many industrialized countries, more salt intake comes from commercial processed foods than from household salt (29). Therefore, salt that is added to these products should be iodized, although that rarely happens. Iodine could be added to commercial foods as iodized salt or directly as part of food fortification premixes together with other micronutrients as appropriate.

The current WHO-UNICEF-ICCIDD guideline recommends salt iodization in the range of $20-40 \mathrm{mg}$ of iodine per $\mathrm{kg}$ of salt (24). Under these conditions, adult men and women satisfy their iodine requirements, consuming 7.5 and $3.75 \mathrm{~g}$ of salt per day, respectively. Salt intake of pregnant and lactating women should be between 6.25 and $12.5 \mathrm{~g}$ /day. The current recommendation for the iodine content of salt is appropriate for the actual amount of salt intake in most populations, but the iodine content should exceed $40 \mathrm{mg} / \mathrm{kg}$ when salt consumption starts to decline.

\section{RATIONALE FOR COORDINATING AND INTEGRATING IODINE FORTIFICATION AND SALT REDUCTION PROGRAMS}

Together, iodine deficiency disorders and cardiovascular diseases associated with high salt intake cause a large burden of preventable illness, impaired development, and premature death worldwide. Optimizing intake of salt and iodine should be a global health priority and there is an urgent need for programs to reduce dietary salt and to improve iodine intake through salt iodization to be closely coordinated to maximize benefit to the public. Not only are the prevention policies and programs for salt reduction and iodine deficiency disorders compatible, but both stand to gain in many ways from close coordination and collaboration. It will be important to monitor intakes of salt and iodine in the population to ensure that they are adequate but not excessive. Similar methods are used to monitor dietary sources and intake and excretion of iodine and salt (dietary surveys and urine collections). Coordination in this and other areas will allow more efficient, less costly utilization of resources.

Altering intake of salt and iodine involves complex discussions and negotiations with the food industry and with population-based and health groups. Jointly coordinated programs would be more efficient in food industry and health sector negotiations; currently, even within the health sector, salt reduction and iodine deficiency control programs are often managed from different areas and are rarely coordinated. In developing economies and economies in transition, there may still be a high proportion of the population (e.g., rural subsistence agricultural, nomadic populations) that adds salt predominantly at the household level, either in cooking or at the table. In this context, efficiencies can be achieved because the population needs ready access to iodized salt, and there is a need for clear messages to use only iodized salt and to reduce the amount of salt used. Coordinating and disseminating those simple consistent messages are critical. Confusing or conflicting messages from uncoordinated programs could mislead people and result in undesirable outcomes, such as high salt intake or fear of using salt at all. Efforts under way in many such contexts to promote the use of iodized salt are a missed opportunity to educate people about the need to reduce salt intake, an issue often perceived as a priority only among urban populations and in high-income countries. For populations that rely more heavily on commercially produced foods, common in economies in transition, coordination and cooperation with the food industry and the areas of the health sector responsible for controlling chronic disease and nutritional deficiency are vital.

\section{RECOMMENDED ROLES FOR WHO, WHO REGIONAL OFFICES, AND INTERNATIONAL PUBLIC HEALTH AGENCIES}

WHO and its regional offices have been active in efforts to optimize the intake of salt and iodine. In 2011, PAHOWHO convened two meetings to help implement the recommendations outlined in the initial WHO report of the 2007 meeting. Substantive implementation issues were identified that need to be addressed to determine how these two health programs are integrated and how people currently running or advocating for national and international programs can coordinate or collaborate to have a greater impact in preventing iodine deficiency and reducing dietary salt to recommended levels. Partly on 
the basis of input from the PAHO-WHO meeting, potential steps $\mathrm{WHO}$, its regional offices, and international public health agencies can take are outlined (Table 1).

\section{RECOMMENDED ROLES FOR NATIONAL GOVERNMENTS}

Most countries have programs to optimize iodine intake and many have considered, or are considering, programs to reduce salt intake. The latter has been more evident in high-income countries and the relevance for low-income countries requires much advocacy. Although programs should be compatible and act synergistically, there are substantive steps national governments must take to ensure optimum intake of salt and iodine. The steps may differ for countries where salt added at home (in cooking and at the table) is the major source of intake and for countries where industrymanufactured foods are the main source of salt. The issue is more complex for countries with economies in transition and the situation is more of a combination of the above two scenarios. There are general steps that national governments can take to coordinate and optimize the intake of both nutrients (Table 2).

\section{RECOMMENDED ROLES FOR HEALTH PROFESSIONALS AND FOR NONGOVERNMENTAL HEALTH ORGANIZATIONS}

Health professionals and nongovernmental organizations should educate themselves about the importance of optimizing intake of salt and iodine, communicate this information to country and donor partners as well as the public where appropriate, and advocate to country and donor partners on the need to coordinate policies and programs. People planning or implementing programs aiming to reduce salt intake need to ensure that their efforts do not have unintended negative effects on iodine intake and consequently lead to iodine deficiency. Similarly, salt iodization programs to prevent iodine deficiency need to ensure that their efforts do not inadvertently impede salt reduction programs. Failure of advocates to address this important concept could cause confusion and potentially harm the population they intend to help. People en-

TABLE 1. Recommended actions for World Health Organization, World Health Organization regional office, and international public health agencies

\begin{tabular}{|c|c|}
\hline $\begin{array}{l}\text { Recommendation } \\
\text { number }\end{array}$ & Action \\
\hline 1 & $\begin{array}{l}\text { Convene meetings, teleconferences, and forums of organizations and key leaders in } \\
\text { iodine deficiency prevention and salt reduction to achieve consensus on the importance } \\
\text { of, and guidance on, coordinating, integrating, and collaborating to optimize intake of } \\
\text { salt and iodine. }\end{array}$ \\
\hline 2 & $\begin{array}{l}\text { Based on experience, produce case studies of how coordination, integration, and } \\
\text { collaboration can work in countries with developing, transitioning, and fully developed } \\
\text { economies. }\end{array}$ \\
\hline 3 & $\begin{array}{l}\text { Devise tools and resources to aid in planning and implementing integrated iodine } \\
\text { deficiency prevention and salt reduction programs including evaluation and monitoring } \\
\text { protocols, educational programs for the public, and approaches to engaging with the } \\
\text { food sector. }\end{array}$ \\
\hline 4 & $\begin{array}{l}\text { Develop and release a position paper on the importance of, and guidance on, } \\
\text { coordinating and integrating programs, which includes implementation resources. }\end{array}$ \\
\hline 5 & $\begin{array}{l}\text { Advocate for the need for salt reduction globally; emphasize that the issue is relevant } \\
\text { not only among high-income populations in developed economies. }\end{array}$ \\
\hline 6 & $\begin{array}{l}\text { Support efforts aimed to compile reliable information about salt intake and iodine } \\
\text { deficiency, particularly in countries with developing and transitioning economies where } \\
\text { this information is currently scarce. }\end{array}$ \\
\hline 7 & $\begin{array}{l}\text { Disseminate information to countries on the importance of and how to integrate } \\
\text { programs to optimize intake of salt and iodine. }\end{array}$ \\
\hline
\end{tabular}

\section{TABLE 2. Recommended actions for national governments}

\begin{tabular}{cl}
\hline $\begin{array}{c}\text { Recommendation } \\
\text { number }\end{array}$ & Action \\
\hline 1 & $\begin{array}{l}\text { Acknowledge the importance of optimizing intake of salt and iodine as a public health } \\
\text { priority and implement an integrated national program to improve intakes of both; } \\
\text { identify clear roles and responsibilities for diverse areas of government that may be } \\
\text { responsible for chronic disease and iodine deficiency control programs. } \\
\text { Convene meetings, teleconferences, and forums of organizations and key leaders in } \\
\text { national iodine deficiency prevention and salt reduction to achieve consensus on how } \\
\text { to develop an integrated national program. If required, enlist international expertise. } \\
\text { Integrate monitoring of salt and iodine intake, blood pressure, and iodine deficiency } \\
\text { to ensure that dietary salt is reduced and that iodine levels in salt and industry- } \\
\text { manufactured foods are appropriately adjusted to level of salt intake. } \\
\text { Develop appropriate messages to the public, health sector, and food sector on the } \\
\text { need to reduce dietary salt and to ensure that whatever salt is used is iodized. } \\
\text { Ensure that iodized salt is available to all for dietary use at home and that food } \\
\text { processing introduces fortification with iodine at appropriate levels. } \\
\text { Determine whether regions or specific population groups in the country are more } \\
\text { vulnerable to low or high iodine intake. Specifically, monitor those regions or groups } \\
\text { and adjust the iodine content of salt to meet their needs as salt consumption declines. } \\
\text { Share lessons with other countries through the World Health Organization or its } \\
\text { regional offices. }\end{array}$ \\
7 &
\end{tabular}

gaged in advocating to correct iodine deficiency need to become advocates for salt reduction and people engaged in advocating for salt reduction need to become advocates for preventing iodine deficiency disorders. This collaborative approach will dramatically increase the strength and likely the impact of both programs. Table 3 indicates common actions and advocacy that health profes- sionals and nongovernmental organizations can take to improve public health in these areas.

\section{CONCLUSION}

Strong, focused programs to optimize intake of salt and iodine have great potential to improve the health of the world's population, but if not coordi- 
TABLE 3. Recommended areas for advocacy, research, and education by health professionals and nongovernmental health organizations

\begin{tabular}{|c|c|}
\hline $\begin{array}{l}\text { Recommendation } \\
\text { number }\end{array}$ & Area \\
\hline 1 & $\begin{array}{l}\text { The importance and need for reducing salt intake and for iodizing salt to improve public } \\
\text { health should be reflected in curricula, communications, and research initiatives. }\end{array}$ \\
\hline 2 & $\begin{array}{l}\text { The need to integrate national salt reduction and salt iodization programs should be } \\
\text { reflected in program planning and implementation. }\end{array}$ \\
\hline 3 & $\begin{array}{l}\text { Intake of salt and iodine, blood pressure, and iodine deficiency should be jointly } \\
\text { monitored to ensure that dietary salt is reduced and that iodine fortification levels in salt } \\
\text { and industry-manufactured foods are appropriately adjusted. }\end{array}$ \\
\hline 4 & $\begin{array}{l}\text { Public awareness programs should be developed to ensure that people understand the } \\
\text { need to reduce dietary salt while ensuring access to and use of iodized salt to prevent } \\
\text { iodine deficiency. }\end{array}$ \\
\hline 5 & $\begin{array}{l}\text { The food industry should reduce the amount of salt added during food processing } \\
\text { and use iodized salt for whatever salt is added (or food should be directly iodized if } \\
\text { appropriate). }\end{array}$ \\
\hline 6 & $\begin{array}{l}\text { National models of food intake should be developed to predict the need for changes in } \\
\text { iodine fortification of salt and industry-manufactured foods and to ensure that intake of } \\
\text { iodine among vulnerable populations is optimal. }\end{array}$ \\
\hline 7 & $\begin{array}{l}\text { Joint surveillance methods to more accurately and easily assess intake of salt and } \\
\text { iodine in populations should be developed and applied in support of the two programs. }\end{array}$ \\
\hline 8 & $\begin{array}{l}\text { Research and implementation of the two programs should identify and specifically } \\
\text { monitor vulnerable populations. }\end{array}$ \\
\hline 9 & $\begin{array}{l}\text { Health models should be developed to estimate the improvement in health from jointly } \\
\text { coordinated iodine deficiency prevention and salt reduction programs. }\end{array}$ \\
\hline
\end{tabular}

nated they have the potential to confuse policy makers, the food industry, and the public, thereby impeding the health goals. Coordinating the programs by sharing and leveraging resources and approaches is more likely to be more cost-effective and more effective overall. Collaboration by those advocating for one or the other program in addition to coordination will provide additional substantive benefits by creating a more powerful lobby sending clear consistent messages to the public, the food industry, and policy makers about the need for appropriate action.

The time for collaboration and coordination is now, as delay is impeding the impact of these important programs to improve public health. The authors call on all organizations and individuals involved in programs to prevent iodine deficiency disorders and those involved in programs to reduce dietary salt intake to join forces and work together in a coordinated and collaborative fashion to the benefit of all.

Acknowledgments. The authors gratefully acknowledge input from Branka Legetic of PAHO and Lucie Bohac of the Micronutrient Institute in developing the concepts for and editing this manuscript. NRCC, OD, and FPC were members of a $\mathrm{PAHO}$ sodium reduction expert group.

Disclosure. This publication does not necessarily represent the decisions or the stated policy of WHO; the designations used and the presentation of material do not imply the expression of any opinion on the part of WHO. A short summary of this topic has been published (34). The authors have no competing interests.

\section{REFERENCES}

1. World Health Organization. Salt as a vehicle for fortification: report of a WHO expert consultation. Geneva: WHO; 2008.

2. World Health Organization. Reducing salt intake in populations: report of a WHO forum and technical meeting, 5-7 October 2006. Geneva: WHO; 2007.

3. Egan BM. Pleiotropic benefits of moderate salt reduction. Hypertension. 2009;54(3):447-8.

4. Panel on Dietary Reference Intakes for Electrolytes and Water, Standing Committee on the Scientific Evaluation of Dietary Reference Intakes. Dietary reference intakes for water, potassium, sodium, chloride and sulfate. Scientific evaluation of dietary reference. Washington, D.C.: National Academies Press; 2004.

5. He FJ, MacGregor GA. A comprehensive review on salt and health and current experience of worldwide salt reduction programmes. J Hum Hypertens. 2009;23(6):363-84.

6. Kearney PM, Whelton M, Reynolds K, Whelton PK, He J. Worldwide prevalence of hypertension: a systematic review. J Hypertens. 2004;22(1):11-9.
7. Vasan RS, Beiser A, Seshadri S, Larson MG, Kannel WB, D'Agostino RB, et al. Residual lifetime risk for developing hypertension in middle-aged women and men. JAMA. 2002;287(8):1003-10.

8. Gaziano TA, Bitton A, Anand S, Weinstein MC. The global cost of nonoptimal blood pressure. J Hypertens. 2009;27(7):1472-7.

9. Committee on Public Health Priorities to Reduce and Control Hypertension in the U.S. Population. A population-based policy and systems change approach to prevent and control hypertension. Washington, D.C.: Institute of Medicine; 2011.

10. He FJ, MacGregor GA. Salt reduction lowers cardiovascular risk: meta-analysis of outcome trials. Lancet. 2011;378:380-2.

11. Cappuccio FP, Capewell S, Lincoln P, McPherson K. Policy options to reduce population salt intake. BMJ. 2011;343:d4995.

12. Strazzullo P, D'Elia L, Kandala N-B, Cappuccio F. Salt intake, stroke, and cardiovascular disease: meta-analysis of prospective studies. BMJ. 2009;339:1-9.
13. Departamento de Epidemiología, Ministerio de Salud, Chile. Chilean health report. Santiago: Departamento de Epidemiología, Ministerio de Salud, Chile; 2003.

14. Danaei G, Ding EL, Mozaffarian D, Taylor B, Rehm J, Murray CJ, et al. The preventable causes of death in the United States: comparative risk assessment of dietary, lifestyle, and metabolic risk factors. PLoS Med. 2009;6(4):e1000058.

15. Asaria P, Chisholm D, Mathers C, Ezzati M, Beaglehole R. Chronic disease prevention: health effects and financial costs of strategies to reduce salt intake and control tobacco use. Lancet. 2007;370(9604):2044-53.

16. World Health Organization. Global status report on noncommunicable diseases 2010. Geneva: WHO; 2011.

17. World Health Organization. Diet, nutrition and the prevention of chronic diseases:report of a joint WHO/FAO expert consultation. Geneva: WHO; 2003.

18. Palar K, Sturm R. Potential societal savings from reduced sodium consumption in the 
U.S. adult population. Am J Health Promot. 2009;24(1):49-57.

19. Zimmermann MB. Iodine deficiency. Endocr Rev. 2009;30(4):376-408.

20. Fordyce FM. Database of the iodine content of food and diets populated with data from published literature. Keyworth, Nottingham: British Geological Survey; 2003.

21. Andersson M, de Benoist B, Rogers L. Epidemiology of iodine deficiency: salt iodisation and iodine status. Best Pract Res Clin Endocrinol Metab. 2010;24(1):1-11.

22. Melse-Boonstra A, Jaiswal N. Iodine deficiency in pregnancy, infancy and childhood and its consequences for brain development. Best Pract Res Clin Endocrinol Metab. 2009;24(1):29-38.

23. Zimmermann MB, Jooste PL, Pandav CS. Iodine-deficiency disorders. Lancet. 2008;372: 1251-62.

24. World Health Organization. Assessment of iodine deficiency disorders and monitoring their elimination: a guide for programme managers. Geneva: WHO; 2007.
25. United Nations Children's Fund-World Health Organization Joint Committee on Health Policy. World summit for childrenmid-decade goal: iodine deficiency disorders (IDD). Geneva: UNICEF-WHO; 1994.

26. Allen L, de Benoist B, Dary O, Hurrell R, eds. Guidelines on food fortification with micronutrients. Geneva: WHO; 2010.

27. Copenhagen Consensus Center. Copenhagen consensus 2008: results. Frederikberg, Denmark: Copenhagen Consensus Center; 2008.

28. United Nations Children's Fund. Sustainable elimination of iodine deficiency: progress since the 1990 World Summit for Children. New York: UNICEF; 2008.

29. Andersson M, de Benoist B, Darnton-Hill I, Delange F, eds. Iodine deficiency in Europe: a continuing public health problem. Geneva: WHO; 2007.

30. Tayie FA, Jourdan K. Hypertension, dietary salt restriction, and iodine deficiency among adults. Am J Hypertens. 2010;23(10):1095-102.

31. Zimmermann MB. Symposium on 'geographical and geological influence on nutrition': iodine deficiency in industrialized countries. Proc Nutr Soc. 2010;69(1):133-43.

32. Leung AM, Braverman LE, Pearce EN. A dietary iodine questionnaire: correlation with urinary iodine and food diaries. Thyroid. 2007;17(8):755-62.

33. Perrine CG, Herrick K, Serdula MK, Sullivan KM. Some subgroups of reproductive age women in the United States may be at risk for iodine deficiency. J Nutr. 2010;140(8):1489-94.

34. Campbell N, Dary O, Cappuccio FP, Neufeld LM, Harding KB, Zimmermann MB. Collaboration to optimize dietary intakes of salt and iodine: a critical but overlooked public health issue. Bull World Health Organ. 2012;90:73-4.

Manuscript received on 4 April 2012. Revised version accepted for publication on 18 September 2012.

RESUMEN El alto contenido de sal en la dieta es una causa principal de incremento de la presión arterial, el principal factor de riesgo de muerte a escala mundial. La Organización Mundial de la Salud (OMS) ha recomendado que el consumo de sal sea inferior a

Necesidad de programas coordinados para mejorar la salud a escala mundial mediante la optimización de la ingesta de sal y yodo

\author{
Palabras clave
}

$5 \mathrm{~g} / \mathrm{d}$, una meta que solo logran una pequeña proporción de personas. La falta de yodo puede causar deficiencia cognoscitiva y motora y, si es grave, hipotiroidismo, con grave retraso mental y del crecimiento. Más de dos mil millones de personas en todo el mundo presentan riesgo de carencia de yodo. La prevención de la carencia de yodo mediante el empleo de sal yodada constituye una importante conquista de salud pública a escala mundial. Los programas cuyo objeto es reducir el contenido de sal en la dieta son técnicamente compatibles con los programas de prevención de la carencia de yodo mediante el enriquecimiento de la sal. Sin embargo, para que las poblaciones se puedan beneficiar plenamente de una ingesta óptima de sal y yodo, es preciso integrar ambos tipos de programa. Este estudio resume las bases científicas de los programas de reducción de sal y enriquecimiento con yodo, la compatibilidad de esos programas, y las medidas que deben adoptar la OMS, los gobiernos nacionales y las organizaciones no gubernamentales para garantizar que las poblaciones se beneficien plenamente de una ingesta óptima de sal y yodo. En concreto, es preciso reunir a grupos de expertos para ayudar a los países a aplicar programas integrados y llevar a cabo estudios de casos en contextos específicos de programas integrados eficaces; es preciso recopilar y difundir las enseñanzas extraídas. La integración de los programas de vigilancia los hará más eficaces y mejorará las iniciativas actuales para optimizar la ingesta de yodo y sal. Para que las poblaciones puedan beneficiarse plenamente, es preciso que los gobiernos asignen una alta prioridad a la integración de estos dos importantes tipos de programas de salud pública.

Sodio; cloruro de sodio dietético; yodo; deficiencia de yodo; nutrición en salud pública; hipertensión; hipotiroidismo; hipertiroidismo. 